\title{
RANGE EXTENSION FOR THE SHORT-TAILED SHREW
}

GARRY R. JONES

Department of Biology, University of Saskatchewan, Saskatoon, S7N 0W0

The short-tailed shrew (Blarina brevicauda manitobensis) is at the northwest limit of its range in Saskatchewan and has been reported from 20 separate locations in the province to date. A review of these capture records and a recent distribution map for Saskatchewan was published by L. S. Riome. ${ }^{2}$
While investigating small mammal populations in cutover areas of the "Mixedwood" section of the boreal forest region of Saskatchewan 3 in 1974 and 1975,36 specimens of Blarina were collected by the author. An additional 10 specimens were taken in 1975 by Mr. Eric Hadley of the Saskatchewan Forestry Association,

TABLE I.

Summary of capture records for the short-tailed shrew in 1974 and 1975 in Saskatchewan.

Location

$9.6 \mathrm{~km}$. SW of

Candle Lake

T54 R23 W2

$3.2 \mathrm{~km}$. NW of above location T54 R23 W2

$7.5 \mathrm{~km}$. S of

White Gull Lake

T56 R21 W2

$9.6 \mathrm{~km}$. N of

Christopher Lake

turn-off (East

of Hwy. No. 2)

T54 R26 W2

$\approx 5 \mathrm{~km}$. W of

Bittern Lake

T57 R27 W2

\section{Month \\ of Capture}

Aug. 1974

June, 1975

July, 1975

Aug., 1975

July, 1975

Aug., 1975

Aug., 1975
Sex of Specimens
No. of Specimens

\section{0,39}

20 , 29

$50,79,1 \mathrm{U}$

$40+59$

20,19

2J, 4SA, 3A

3

1

19

$1 \mathrm{~A}$

$1 \mathrm{~J}, 2 \mathrm{~A}$

$2 \mathrm{~J}, 2 \mathrm{~A}$

7J, 1SA, 5A

$1 \mathrm{~J}, 2 \mathrm{~A}$

gory

J, $4 \mathrm{~A}$

420,2 은 $2 \mathrm{~J}, 2 \mathrm{~A}$

13

9




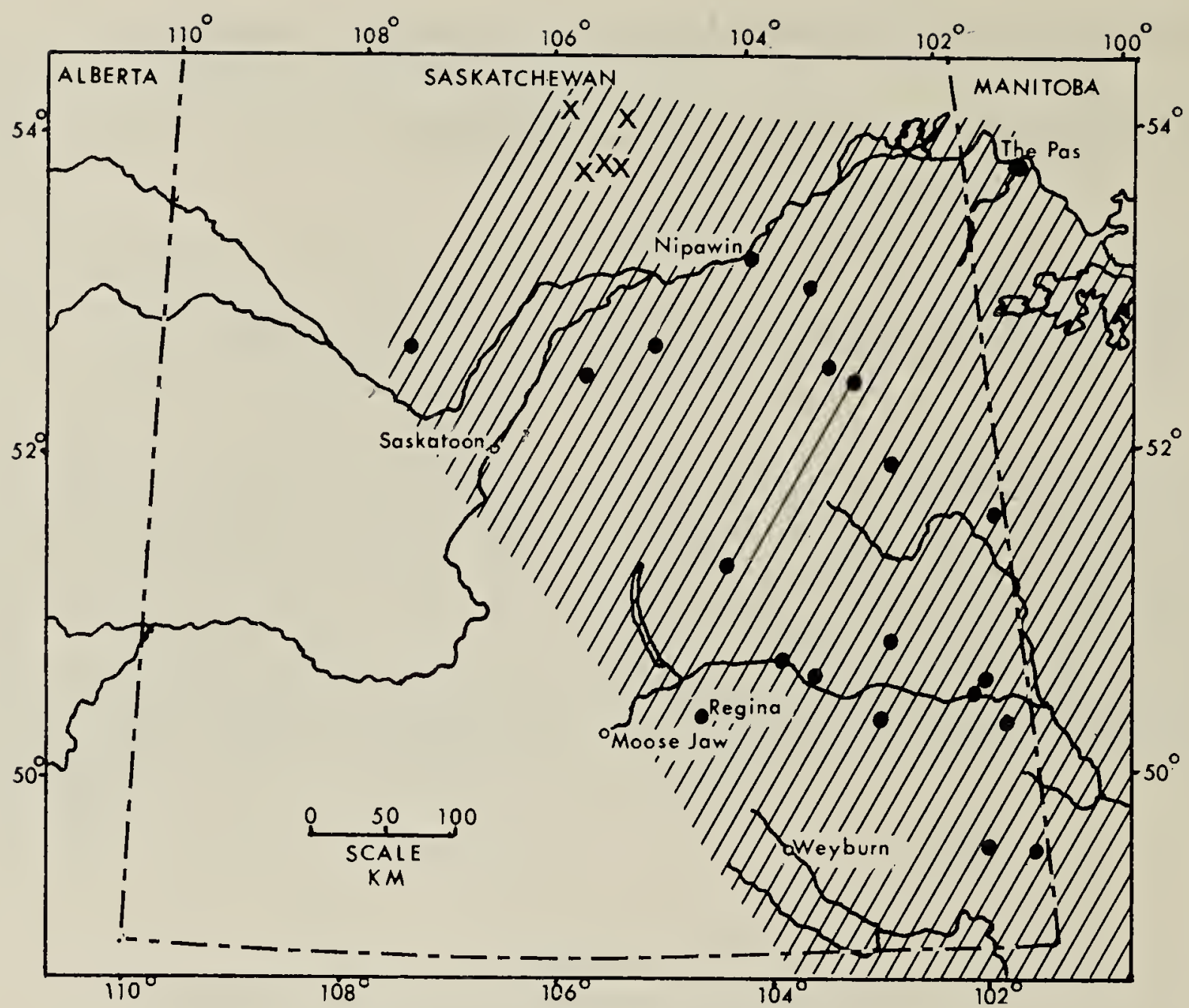

Figure 1. The distribution of Blarina brevicauda manitobensis in Saskatchewan. New records are marked $\mathrm{X}$.

who was conducting similar studies in a cutover area west of Bittern Lake (T57 R27 W2). Mr. Hadley was kind enough to contribute his records to this report. The shrews were taken with Museum Special break-back traps baited with peanut butter. A summary of the new capture records is presented in Table I. Average measurements for adult specimens taken by the author were as follows: total weight $22 \mathrm{gm}$ (19-26), total length $130 \mathrm{~mm}$ (125$134)$, tail $25 \mathrm{~mm}(22-28)$, hind foot 15 $\mathrm{mm}$ (14-16); for juvenile specimens: total weight $16 \mathrm{gm}(14-17)$, total length $121 \mathrm{~mm}(114-126)$, tail $25 \mathrm{~mm}$ (23-28), hind foot $14 \mathrm{~mm}$ (13-15). Average measurements for the adult specimens contributed by Mr. Hadley were as follows: total length $126 \mathrm{~mm}$ (112-129), tail $23 \mathrm{~mm}$, hind foot 15 $\mathrm{mm}$ (14-17); for juvenile specimens: total length $118 \mathrm{~mm}$ (106-129), tail 25 $\mathrm{mm}$ (22-28), hind foot $15 \mathrm{~mm}$ (14-17). Total weights were not available.

The new records represent a northern range extension for the short- tailed shrew in Saskatchewan. The distribution map (Fig. 1) is modified from Riome (1968) to include the new records.

The short-tailed shrew is a fossorial insectivore which prefers high humidity and decaying leaf litter as optimum environment.' It is, therefore, possible that Blarina may be found even farther north in Saskatchewan, in association with moist, deciduous habitats.

The author gratefully acknowledges the assistance of $\mathrm{Mr}$. W. H. Beck in confirming the validity of these new records as representing a range extension for Blarina in Saskatchewan.

'BANFIELD, A. W. F. 1974. The Mammals of Canada. University of Toronto Press 1974, 438 p.

${ }^{2} \mathrm{RIOME}$, L. S. 1968. Short-tailed Shrew at Nipawin. Blue Jay 26: 201-203.

${ }^{3}$ ROWE, J. S. 1972. Forest Regions of Canada. Department of the Environment, Canadian Forestry Service Publ. No. 1300, 172 p. 